\title{
Lender representatives on board of directors and internationalization in firms: an institutionalized agency perspective
}

\author{
Vidya Sukumara Panicker ${ }^{1}$ D $\cdot$ Rajesh Srinivas Upadhyayula ${ }^{2} \cdot$ Sumit Mitra $^{2}$
}

Accepted: 9 September 2021 / Published online: 21 September 2021

(c) The Author(s) 2021, corrected publication 2021

\begin{abstract}
From an agency perspective, the Anglo-Saxon features of corporate governance are predominantly explored by various studies in extant literature. However, it has recently been established that diverse and unique institutional configurations exist in different economies across the world and hence, the attitude of different actors within a firm, as shaped by institutional logics, can vary. Our study applies the institutionalized agency perspective to understand how the behaviour of different actors, within firms in the Indian institutional context, are shaped, consequently determining their roles in the strategic decisions of firms. We examine the representation of lenders in the board of directors, which is a characteristic of corporate governance in India. Our sample for this study consists of 985 unique Indian firms and 5513 firm year observations across the 2006-2017 time-period. We find a negative association between the proportion of lender representatives on board of directors and internationalization of firms. In addition, we also find that family ownership positively moderates this relation, whereas foreign institutional investors and domestic banks and financial institutional investors moderate this relationship negatively. In this manner, we explore the impact of institutional environment on a very specific actor (lenders) and their representatives towards internationalization.
\end{abstract}

Keywords Anglo-Saxon models · Institutional configurations · Corporate governance $\cdot$ Internationalization $\cdot$ Lender representation

Vidya Sukumara Panicker

v.s.panicker@lboro.ac.uk

Rajesh Srinivas Upadhyayula

rajesh@iimk.ac.in

Sumit Mitra

smitra@iimk.ac.in

1 School of Business and Economics, Loughborough University, Loughborough, UK

2 Indian Institute of Management, Kozhikode, Kerala, India 


\section{Introduction}

Extant literature on Anglo-Saxon models of corporate governance posits that board of directors are instrumental in negotiating the agency conflicts between owners and management (Baysinger \& Butler, 1985; Boubaker et al., 2015; Boyd, 1994; Dalton et al., 2007). Consequently, studies have examined as to how various board characteristics viz., independent directors, CEO duality and others protect the interests of shareholders through active involvement in various strategic decisions (Baysinger \& Hoskisson, 1990; Dalton et al., 1998; Goodstein et al., 1994). Accordingly, the board acts as a bridge between the owners and the management (Van den Berghe $\&$ Levrau, 2004). However, in several other countries of the world, majority ownership is held by large owners such as banks, corporates, or families, and therefore, the type of agency conflicts that the firms in these countries face is different from that established in the western contexts (Dharwadkar et al., 2000; Melis et al., 2012; Morck et al., 2005; Young et al., 2008). In this setting, the board of directors cannot fulfil their traditional monitoring obligations but are instead active as resource providers (Panicker \& Upadhyayula, 2020; Yoshikawa \& Phan, 2005). However, extant literature prioritises Anglo Saxon system in understanding of the role/features of the board, such as independent directors and CEO duality. Such limited view of corporate governance owing to specific Anglo-Saxon characteristics of board such as board independence, while ignoring many characteristics relevant to other models of corporate governance, has been criticized in literature (Pucheta-Martínez \& García-Meca, 2014). Moreover, studies have argued that classifying corporate governance systems into stylized and broad categories of Anglo-Saxon or otherwise itself is faulty since unique institutional configurations exist in different countries of the world (Aguilera \& Jackson, 2003; Aguilera \& Yip, 2004). These configurations could subsequently result in different national level institutional characteristics prevailing in different countries and impacting strategic decision of firms (Fainshmidt et al., 2018). We aim to fill this gap by understanding a distinct feature of boards of directors across certain institutional contexts, viz., the presence of lender representative, in the board of directors, on internationalization of emerging market firms.

Internationalization of emerging economy firms is an interesting phenomenon that has grown in importance over the years, especially in those countries with a limited domestic market (Ruzzier \& Antoncic, 2007). Emerging market firms internationalize due to their need to expand owing to limitations of domestic markets as well as due to their increasing confidence (Luo \& Rui, 2009; Ramamurti, 2009). Further, internationalization strategy is a high-risk strategy primarily due to the uncertainties associated with it (Johanson \& Vahlne, 2009; Vahlne \& Johanson, 2013). These uncertainties arise not only from the domestic and international business environments that the firm operates in, but also from the industry and within the firm as well (Miller, 1992; Wernerfelt \& Karnani, 1987). These associated risks can, therefore, cause the failure of international investments (Clarke \& Liesch, 2017).

The presence of lender representatives in the board is one of conflicting interests; of safeguarding the interests of the lender institution that they represent on 
one side, and their responsibility towards the larger group of shareholders on the other (Dewatripont \& Tirole, 1994; Jensen \& Meckling, 1976). Against the backdrop of increasing stakeholder capitalism (Freeman \& Liedtka, 1997; Freeman et al., 2007), it may even be argued that the interests of lender institution could clash not just with the shareholders, but also with the larger group of stakeholders, including all external and internal stakeholders of the firm. However, in this study, we focus our attention on impact of lender presence on the interests of one group of stakeholders of the firm, specifically the shareholders of the firm. Even while the larger groups of shareholders of a firm might support their highrisk activities such as internationalization promising high returns, the lender representatives can assume a risk-averse stance by standing against such highrisk strategies, preferring to ensure continuing revenue flow and loan repayment from the firms (Jensen, 1986; Kroszner \& Strahan, 2001). The presence of these representatives becomes even more interesting when some of these lenders are also shareholders in the firms (Pucheta-Martínez \& García-Meca, 2014; Sarkar \& Sarkar, 2000). Therefore, institutions such as banks and other financial institutions have a dual relationship with the firm, in the form of both lender and investor (Chirinko \& Elston, 2006). Potentially serious conflicts of interest can evolve out of this dual relationship within such institutions (Pan \& Tian, 2015; Welch, 1997). In this context, the overall impact of lender representatives on the internationalization choices of a firm, becomes a pivotal question.

Further, comparative corporate governance literature examines the limiting role of agency theory in explaining the nature of relationships among various stakeholders and their strategic choices (Aguilera \& Jackson, 2003; Band, 1992). There is a constant interplay between actors and institutions and institutions often dictate the norms of behaviour followed by different actors within the firm (Aguilera \& Yip, 2004). Thus, agency theory is constrained in its thin view of the institutional environments and offers limited explanations for contexts distinctly different from Anglo-Saxon governance systems. Alternatively, an institutionalized agency perspective (Aguilera \& Jackson, 2003; Greenwood et al., 2014; Seal, 2006), which recognizes the importance of institutional environment in which firms and their owners are situated, could offer us a more complete understanding of how the institutions shape the way in which different owners (e.g., banks and financial institutions, foreign institutional investors and families) pursue different interests owing to the institutionally defined rules governing them. In this paper, we employ the institutionalized agency lens to specify how the role of each corporate governance actor (such as different types of owners and board of directors) is shaped by national institutional characteristics, the interactions resulting from the conflicts and coalitions among them, and the overall outcomes on firm internationalization.

We use India as a case to test our model. On our panel which consists of 5513 firm years (985 individual firms) of Indian firms over a 12-year duration (2006-2017), we use Tobit random effects panel regression technique. Our results show that lender representatives on board negatively affect internationalization of Indian firms. We also find that higher share of ownership by institutional investors such as banks and financial institutions as well as foreign institutional investors negatively moderate the relation between lender representatives and internationalization. However, the 
interaction between family owners of firms and lender representatives on the board of these firms has a positive influence on internationalization of firms.

Our work contributes to the extant literature and practice in the following ways. First, we focus our attention on an under-researched area in internationalization literature, the relation between lender representative on the board of directors and internationalization. Our research on lender representatives in board is also a response to the criticism of corporate governance research focusing predominantly on Anglo-Saxon characteristics of governance, while ignoring those characteristics that are unique to other institutional contexts. Second, we understand the interaction patterns between lenders and shareholders in the board of directors, and the overall effect on internationalization as a firm strategy. While the lender-investor interaction has been understood in various contexts, its impact on internationalization of firms is little explored in extant literature. We expand this understanding by employing the Varieties of Institutional Systems framework (Fainshmidt et al., 2018), and explore how institutional environment shapes the behaviour of an actor, thereby impacting their preferences for risky firm strategies. Finally, from a managerial perspective, we find that lender representation on the board of directors is not beneficial for a firm considering internationalization, even if the institutional investors are keen on such investments. At the same time, family firms gain significantly from lender representation, and the information advantages and low-cost capital in this transaction promotes internationalization in firms.

\section{Literature review and hypotheses development}

\subsection{Institutional systems and Corporate Governance models}

Corporate governance systems vary across countries, firms, and industrial sectors in terms of ownership, control, identity of owners and regulatory mechanisms (Maher $\&$ Andersson, 2002). While corporate governance models are traditionally classified into two; Outsider model and Insider model (Shleifer \& Vishny, 1997), more recent studies reveal further institutional configurations that could result in unique governance models across different contexts (Fainshmidt et al., 2018; Hall \& Soskice, 2001). For instance, the institutional configurations reflected by the state, financial markets, human capital, social capital, and corporate governance institutions across different regions vary, and can consequently influence firm decisions.

The traditional Varieties of Capitalism (Hall \& Soskice, 2001) and National Business Systems (Whitley, 1999) frameworks which have been effective in examining the characteristics of developed markets, are often ineffective in examining the institutional configurations of emerging and developing economies (Tsui-Auch \& Lee, 2003). Varieties of Capitalism typology classifies developed markets in to liberal and coordinated markets through a profit, risk and resources perspective (Hall \& Soskice, 2001) and is criticized for overlooking aspects of developing countries (Fainshmidt et al., 2018). Further, National Business Systems identifies how economic activities are shaped by different actors within a specific institutional context (Whitley, 1999) but is often criticized for its inability to represent systems such as 
state and family capitalism (Musacchio et al., 2015; Tsui-Auch \& Lee, 2003). In this regard, a "Varieties of Institutional Systems" framework (Fainshmidt et al., 2018, pp. 308), could offer more specifications regarding the institutional systems (including corporate governance) in emerging markets, such as India. Such an approach towards institutional system is beneficial in examining a variety of strategic outcomes in firms, including internationalization ( $\mathrm{Lu}$ et al., 2014; Pajunen, 2008; Witt \& Lewin, 2007). As per this, emerging markets such as India fall under the institutional configuration of countries with high levels of state dominance and intervention, weak equity markets, strong credit markets led by banks and high levels of ownership concentration in firms (Fainshmidt et al., 2018). Thus, different elements of this configuration result in unique corporate governance characteristics, that differentiate one institutional context from the other.

In this light, studies often employ an integrated theoretical perspective, often addressed as institutionalized agency theory, which examines corporate governance practices and decision making within firms as an outcome of institutional factors that define and represent the behaviour of actors (Aguilera \& Yip, 2004). This emanates from the underlying assumption that different types of investors are governed by different institutionally defined rules and hence, they pursue different interests within the firms. At the same time, there is an ongoing ambiguity in the definition and applications of different theoretical lenses within institutional theory (Aguilera \& Grøgaard, 2019; Jackson \& Deeg, 2008). For instance, Aguilera and Grøgaard (2019) explain that institutions can mean the rules of the game, a source of pressure towards isomorphism or a combination qualifier to create new research terms. In our study, we follow the neo-institutional literature that posits that organizational behaviour is shaped in response to social pressures arising from the environment (Immergut, 1998; Suddaby et al., 2013). Because this theoretical aspect can also explain behaviour of actors within the firm that defies economic rationales as defined by agency theory (Drori et al., 2003), the neo-institutional perspective within institutional theory is appropriate to be integrated with agency theory in explaining the behaviour of different actors within the firm and firm strategies (e.g., Bao \& Lewellyn, 2017; Gerlach et al., 2013; Seal, 2006).

In our study, by applying institutionalized agency perspective to corporate governance, we attempt to understand the interplay of institutions and firm-level actors (Scharpf, 2018). The way the preferences of actors are defined, aggregated, and represented within a firm depends on the social and political processes shaped by the institutions (Aguilera \& Yip, 2004; Scharpf, 2018). The institutionalized agency model as applied to our case, therefore, specify how the role of different governance actors such as ownership groups and board of directors are shaped by the national institutional domain and the consequent patterns of interactions which influence firm strategies.

\subsection{Lender representatives on board and internationalization}

A direct outcome of the increasing role of banks and financial institutions in certain institutional configurations is the presence of lender representatives in the board of 
directors (e.g. Dittman et al., 2009; Ghosh, 2016; Kroszner \& Strahan, 2001; Yoshikawa \& Phan, 2005). There are several debates surrounding their participation as a board member. Studies that examine the role of lender representatives on board of directors in the context of developed countries such as Unites States suggest that lender representatives offer several advantages to firms, such as improved information symmetry, (Kroszner \& Strahan, 2001), positive market signalling (Byrd \& Mizruchi, 2005; Kroszner \& Strahan, 2001) and lowering the overall costs of external finance for strategic investments (Fama, 1985; James, 1987; Kracaw \& Zenner, 1998).

However, as an important actor in a bank-dominated institutional environment, there exists multiple relations between lenders and the firm. For instance, Hopt and Leyens (2004) document that in their multiple roles as a lender, an investor, and a participant in the firm (in the form of board representation), lending institutions face severe conflict of interest in the activities of their investing firms. Since directors representing the lenders are present on the board of directors in lieu of the lender relationship of their respective institution or lending entities with the firms, they are normally appointed when the loan term begins and are withdrawn as soon as the loans are repaid (Nachane et al., 2005; Sarkar \& Sarkar, 2000). This implies that their primary responsibility need not be in the interest of the firm or the larger set of shareholders but towards the lending institution that they represent (Pan \& Tian, 2015; Welch, 1997). As a lender, the priority of the institution would be the repayment of the loan that the firm holds, and for the firm to engage in safer and low-risk growth strategies to ensure a steady repayment (Dewatripont \& Tirole, 1994; Jensen $\&$ Meckling, 1976). Kroszner and Strahan (2001) point out that this ensuing conflict of interest among lenders is extreme in firms that are encountering high-risk strategies (such as internationalization). Consequently, a lender with a representative on the board expects the directors to protect its interest as the lender to the firm, and therefore would seek them to oppose high-risk, long term investment of the firm, such as internationalization. Therefore, the lender representative would utilize their participation in the board of directors of the firm towards lowering the chances of internationalization of an invested firm. Subsequently, we hypothesize the following:

Hypothesis 1: Lender representatives on the board of directors is negatively associated with internationalization of firms.

\subsection{Ownership groups as moderators in lender-internationalization relation}

Studies have established that different groups of owners have distinct preferences towards strategies such as internationalization (e.g., Lin, 2012; Panicker et al., 2019). In many contexts, family firms are found to have a lower preference towards internationalization of their firms, to protect their socio-emotional wealth in the emerging economy context (e.g., Bhaumik et al., 2010; Fernandez and Nieto 2005; GomezMejia et al., 2007; Panicker et al., 2019). It was also found that different groups of institutional investors such as domestic investors, pension funds, mutual funds and foreign institutional investors have varying influence on internationalization in 
firms (e.g., Bhaumik et al., 2010; George et al., 2005; Lien et al., 2005; Panicker et al., 2019). Conflicts of interests between shareholders (owners) and lenders is documented in literature (Dewatripont \& Tirole, 1994; Jensen \& Meckling, 1976; Kroszner \& Strahan, 2001). For instance, it is argued that in comparison to lenders, shareholders prefer higher risk strategies with possible higher returns (Kroszner \& Strahan, 2001). This conflict is further exacerbated when lender has a representative on the board of directors, since the primary accountability of the board is towards shareholders and the board also holds fiduciary responsibilities towards the shareholders (Becker \& Strömberg, 2012). We further hypothesize on the interaction between different categories of shareholders (owners) and lender representatives on board of directors.

\subsubsection{Family ownership and lender representatives}

Increased ownership and interference in business activities by family is a characteristic of many institutional configurations including Indian (Fainshmidt et al., 2018; Purkayastha et al., 2018). This increased intervention by family can have implications on lender behavior as well. Family ownership can moderate the internationalization preferences of lender representatives in the board of directors predominantly by influencing the risks that lender representatives associate with strategic decision of firms. Family ownership is reflective of the voids that exist in institutional environment, and consequently, family ownership can enable firms in circumventing several inadequacies and challenges of the environment (Chang \& Choi, 1988; Khanna \& Palepu, 1997, 2000; Bodnaruk et al., 2012). Further, family-owned firms also enjoy advantages such as easy access to labor and product markets (Gaur \& Kumar, 2009; Khanna \& Rivkin, 2001), which lowers the overall risk perception of other stakeholders such as the lenders and lender representatives. Therefore, family ownership is instrumental in reducing the risk perception that lender nominees associate with internationalization decisions. Additionally, it has been found that family firms often build stable, long-term and reciprocal relations with their lenders (Arrègle et al., 2007; Molly et al., 2010; Sanchez-Bueno and Usero 2014). These relationships and social ties also prompt lenders and their nominees on board to be supportive of internationalization of firms with significant family ownership.

Therefore, we hypothesize the following:

Hypothesis 2: Family ownership moderates the lender representative-internationalization relation in such a way that this relation is less negative in firms with higher levels of family ownership.

The role that foreign institutional investors play in firms in a specific institutional context also depends on the corporate governance at the national level as well as the specific firm level characteristics (Aguilera \& Jackson, 2003; Fiss \& Zajac, 2004; Tuschke \& Sanders, 2003). Thus, the interaction between international players and specific aspects within an institutional configuration can alter the firm level decisions (Djelic, 2001). As international entities, their investment 
experience and expertise give foreign institutional investors high information advantage in firms where they invest (Dvořák, 2005). Given their relatively larger holdings, shareholders such as foreign institutional investors have sufficient incentives in monitoring their investee firms (Gillan \& Starks, 2003), which individual shareholders do not possess. Consequently, foreign institutional investors are found to be strong external monitors of firms (Huang \& Zhu, 2015). These investors have been found to actively use their ownership rights, such as voting and involving themselves in the corporate governance of a firm (World Bank, 2005). The advantages offered by foreign institutional investors in internationalization of their investee firms is well documented in literature (Bhaumik et al., 2010). With this active monitoring role that they play, foreign institutional investors can influence lender preference for internationalization in a specific manner as discussed hereafter.

Foreign institutional investors are found to be equipped with globally diversified investment portfolios which enable them to be supportive of risky commitments in internationalization ventures (Panicker et al., 2019). In addition, it is known that foreign institutional investors have ability to identify firms with better corporate governance mechanisms. In this role, foreign institutional investor shareholdings in a firm can help attract investors (Douma et al., 2006) as well as act as a signal mechanism for lenders in supporting decisions of the firm to internationalize. This results in foreign institutional investors developing confidence of the lender representative in decisions related to internationalization, by giving positive signals about the health of the firm as well as through their experience in international activities. Further, it has also been understood that effective monitoring by foreign institutional investors can reduce the cost of debt from lending institutions (Tee, 2018). This translates to a case where lender representatives are more confident of funding and supporting internationalization investments in firms with foreign institutional investor ownership. Consequently, we hypothesize,

Hypothesis 3: Foreign institutional investor ownership moderates the lender representative-internationalization relation in such a way that this relation is less negative in firms with higher levels of foreign institutional investor ownership.

In institutional configurations where the credit market and banks play a significant role, banks and financial institutions can also be investors in the firm who hold lending relations with the firms. Such dual relations are common in many countries, and the lending role of such institutions is found to strengthen their investor role (Dwivedi \& Jain, 2005; Hopt \& Leyens, 2004; Sarkar \& Sarkar, 2000). Therefore, even when the lender representatives directly represent the lender to a firm, they are also a source of information for the same lending institution's investments in the firm. Therefore, lender representatives in their dual role of representing the same institution's lending and investing activities in a firm protect both the interests. Due to such dual role of institutions as banks, insurance companies and other financial entities, they are handicapped in taking 
high risk strategies such as internationalization. Domestic institutions such as banks and financial institutions may not have the required expertise or experience in specialized investment strategies such as internationalization (Giannetti \& Ongena, 2005; Goldberg et al., 2000). Therefore, these shareholders are expected to oppose internationalization moves in invested firms. In specific institutional context we argue, having lender representatives on board is a mechanism through which banks and other financial institutional investors can exert control over the board of an invested firm, and monitor its decisions more effectively (Black, 1992). Therefore, we argue that the duality of investor and lender role of financial institutions, further discourages lender representatives on board of director of firms from undertaking internationalization.

Hypothesis 4: Ownership by banks and financial institutions moderates the lender representative-internationalization relation in such a way that this relation is more negative in firms with higher levels of bank and financial institution ownership.

\section{Research methodology}

\subsection{Context and data}

The sample for this study consists of publicly listed Indian companies. In India, shareholder in firms can exist in the form of controlling shareholders (such as the founding family), as well as non-controlling shareholders (such as institutional investors and other dispersed shareholders) (Balasubramanian \& Anand, 2013; Sarkar, 2010). Another major institutional characteristic of the country is the significance of banks and financial institutions as a source of corporate finance (Dwivedi \& Jain, 2005; Fainshmidt et al., 2018; Sarkar \& Sarkar, 2000). At the same time, it is to be noted that Indian firms rely on both banks and capital markets to finance long term projects (Singh, 1999). Thus, both equity governance and debt governance are important to Indian firms.

We extracted our data sample from the Prowess database published by the Centre for Monitoring Indian Economy (CMIE). This database holds the data on the financial, ownership and board of directors of Indian firms. Our initial dataset consisted of all listed Indian firms from the database, in the time-period of 2006 to 2017 . We choose 2006 as the starting point of our dataset and analysis since the Clause 49 (listing agreement of the Securities and Exchanges Board of India) predominantly came to existence in phases between 2000 and 2005. Therefore, these reforms on corporate governance in India would reflect on the firm level activities from 2006 onwards (Panicker et al., 2019). Further, we also anticipate greater consistency in disclosure practices from this time-period (Abraham et al., 2015).

From the initial sample of the larger set of firms, we dropped all data points with missing data. Further, we also removed firms belonging to finance, insurance, and real estate industries as these firms follow a separate corporate governance regulatory regime (Jaiswall \& Banerjee, 2012). In the final sample, we have firms representing 6 industry sectors (Agriculture, Construction, Manufacturing, 
Mining, Services and Transportation). These classifications were identified as per the National Industry Classification (NIC) code. The final sample of firms with internationalization in the time period consisted of 5513 firm years of 985 unique firms.

\subsection{Variables}

The dependent in this study is internationalization of firms. We measure internationalization as the ratio of Export sales to total sales (ESTS), computed as the proportion of export sales to total annual sales (e.g., Fuad \& Gaur, 2019; Ray et al., 2018; Singla et al., 2014).

We compute lender proportion on board of directors as a ratio of the number of lender representatives to the total size of the board (total number of board of directors) (Ghosh, 2016; Kroszner \& Strahan, 2001). The lender representatives were identified from the board of director details available in the Prowess database of CMIE. This database includes the type of board of directors, which indicates whether a director is unaffiliated or affiliated to an institution. As a first step, we remove the unaffiliated directors from the list since they have no affiliation to an external entity. The remaining affiliated directors could be a nominee of the state or central government, employee representative, NRI representative or representative of a lender. After we removed the others from the list, we were left with lender nominees in each firm, which we used to compute the proportion of lender representatives on the board.

We compute family ownership as the equity held by family owners. This includes both the shares held by family owners as well as corporate promoters since intercompany and pyramidal holdings are common in the Indian context (Ashwin et al., 2015). Institutional ownership was measured as a proportion of shares held by different institutional investor groups. We have two variables related to institutional ownership; one indicating the percentage of shares held by foreign institutional investors and the other indicating the shareholding by banks and other financial institutions. The latter classification includes the shareholding by banks and all other financial institutions that provide financial services and excludes asset Management Companies and insurance companies which hold alternate relations with the firm.

We also control for several variables, based on our review of extant literature. First, we control for board size computed as the total number directors on the board, and board independence measured as the proportion of independent directors to total number of directors (Panicker \& Upadhyayula, 2020; Singh \& Gaur, 2013). Next, the business groups affiliation of the firms is indicated through a dummy variable that takes value 0 for unaffiliated firms and 1 otherwise (Ashwin et al., 2015). Other financial variables that can potentially impact internationalization are also identified and controlled for. These include firm size measure as total assets, profitability measured as ROA (Return on assets), R\&D intensity measured as the proportion to R\&D expenditure to total sales, Debt to Equity ratio, age of the firm and the primary industry of operation of the firm (Panicker \& Upadhyayula, 2020; Ray, et al., 2018). 


\subsection{Methodology}

To test our model, we employ GLS estimation. GLS estimation was chosen over pooled OLS since this method can correct for the presence of heteroskedasticity and autocorrelation in the data (Wooldridge, 2002). Further, we apply random effects estimation over fixed effects due to two reasons. First, the Hausman test on our sample showed that our model was not violating any of the assumptions of random effects estimation. Second, our model consists of several time invariant variables such as group affiliation dummy and industry of operation, which can be effective only in a random effects model. We also lag our independent variables by one year to reflect the typical length of a diversification decision-implementation cycle.

\section{Results}

Table 1 presents the descriptive statistics and correlation matrix. From Table 1, we find a high level of collinearity between certain variables. To confirm that our model does not suffer from multi-collinearity, we computed the Variance Inflation Factors (VIF). A consistently low VIF, well below the accepted cut off 4, shows that our model does not suffer from multicollinearity. Also, due to the high variance, we compute and use the log of firm size and ROA in our analysis.

In all cases, we perform hierarchical regressions on our sample. Model 1 is for controls only, model 2 introduces lender proportion in the model. In models 3, 4 and 5 , we introduce the interaction effects one by one, with model 6 including all interactions together. Table 2 presents the outcomes of GLS panel regression examining the direct and moderated impact of lender representatives on firm internationalization.

From models 2 to 6 in Table 2, we find that lender representation is negatively associated with the internationalization in our sample. This provides support for hypothesis 1 . From model 3, the interaction effect of family on the lender representation-internationalization effect is positive, thereby supporting hypothesis 2 . However, model 4 shows a negative moderation effect of foreign institutional investor ownership on the lender representation-internationalization relation, thereby rejecting hypothesis 3. Finally, model 5 shows that institutional investors such as banks negatively moderate the relation between lender representation and internationalization, as hypothesized. Thus, we find support for Hypothesis 4.

\subsection{Robustness tests}

We have performed some additional analyses to ensure the robustness of our outcomes. Since our sample consists of only those firms that have lender representation on their boards, there is a potential selection bias in the sample and outcomes. Inorder to methodologically address this selection bias, we employ Heckman 2-stage estimation techniques (Heckman, 1976). To perform the 2-stage estimation, the first stage requires identifying variables that satisfy the exclusion restriction to address 


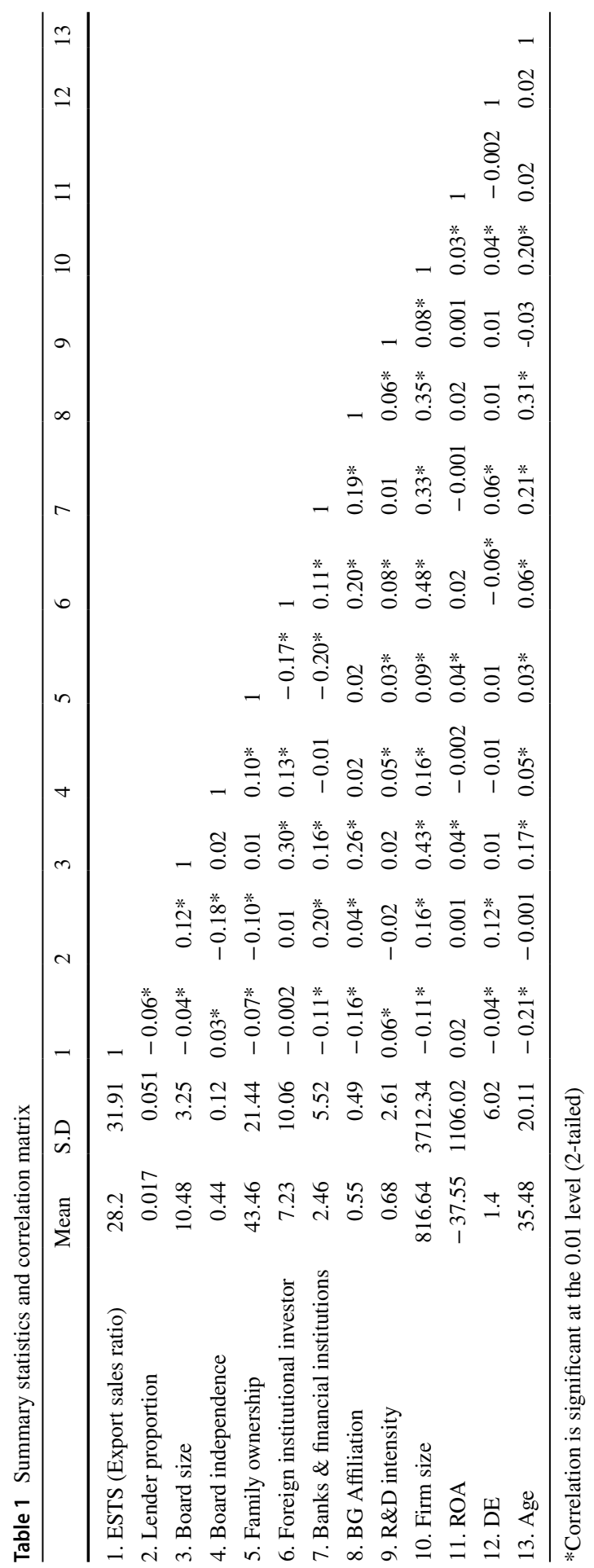




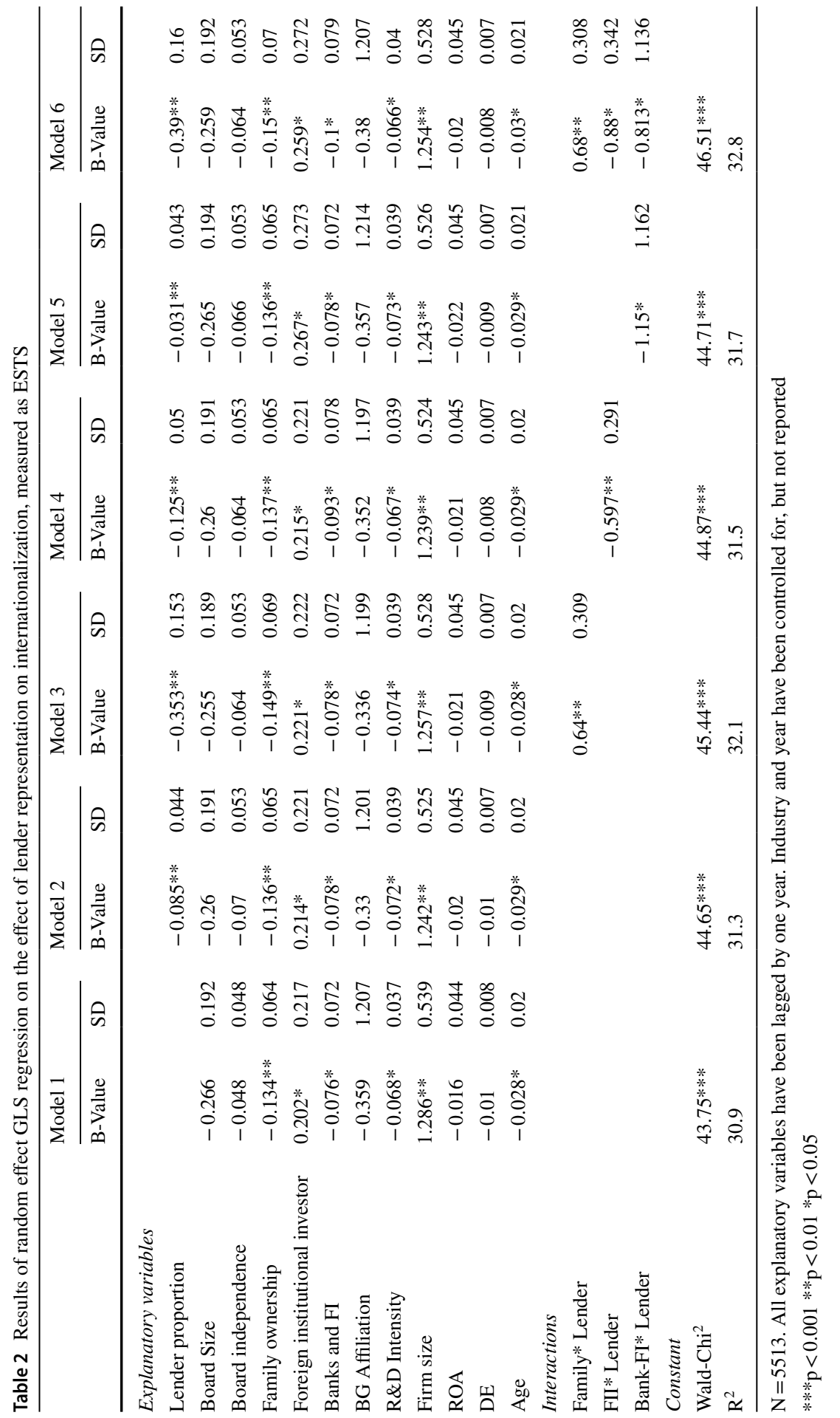


the identification problem (Sartori, 2003). In this stage, we use a probit model and analyse the determinants of lender representation in the board of directors of firms. An analysis of extant literature helped us identify the variables that determine lender representation in the board of firms, viz., short term debt, long term debt, tangible assets, cash holdings scaled to total assets and market to book ratio, along with the variables in the initial analysis (Hilscher \& Şişli-Ciamarra, 2013; Kang \& Kim, 2017). These variables constitute the selection model in the stage- 1 of the analysis. Stage 1 of Table 3 presents the results of the selection model. Our results show that, among other factors, those firms with high levels of long-term debt, low levels of tangible assets, low cash to asset ratio, low market to book ratio, larger boards and higher bank ownership have a higher probability of lender representation in their board of directors.

The inverse Mills ratio thus generated in the first stage is an independent variable in the second stage regression. Stage 2 model in Table 3 presents our results. We see that even after controlling for the selection biases, our results remain consistent with the initial results.

\section{Discussion and conclusion}

In this study, we examine the role of a specific feature of certain institutional configurations i.e., presence of lender representatives on the board of directors, from an institutionalized agency perspective. We find that the lender directors are negatively associated with internationalization of Indian firms. This brings the lender representatives at cross-roads with other categories of directors such as independent directors, who are found to support internationalization activities in firms (Singh \& Delios, 2017). In addition, we find that the relation between lender directors and internationalization is also contingent upon the ownership structure of the firm. While the ownership by institutional investors such as banks as well as foreign institutional investors negatively moderate this relationship, family ownership has a positive moderating effect on the relation. We contextualize and elaborate our results further.

Our results show that unlike independent directors, lender representatives do not function to support the interest of the larger group of shareholders of a firm or support risky growth strategies of firms. Therefore, the lender representatives do not perform a resource provisioning role to firms in their internationalization activities which they view as risky growth strategy. This could be due to the biased behaviour that they exhibit towards the lending institutions that they represent. First, as the representative of the lending firm, they support the interests of the firms they represent. Since lending organizations prefer low risk strategies that ensure cash flow in firms, their representatives are reluctant to support internationalization activities in firms. In addition, unlike independent directors, the lender representatives do not have the requisite boundary spanning role that brings knowledge/information and other resources to the firms to influence their internationalization activities. Recent studies have already shown that the nature of inter-relationships between various stakeholders of the firm is dependent on the institutional conditions, which affect their 
Table 3 Results of Heckman 2 stage regression on the effect of lender representation on internationalization

\begin{tabular}{lll}
\hline & $\beta$-value & SD \\
\hline Heckman stage 1, DV: Presence of lender representatives & & 0.001 \\
Short term debt & -0.001 & 0.002 \\
Long term debt & $0.004^{*}$ & 0.001 \\
Tangible assets & $-0.002^{* *}$ & 0.228 \\
Cash to asset ratio & $-0.05^{* *}$ & 0.007 \\
Market to book ratio & $-0.033^{* *}$ & 0.02 \\
Board Size & $0.0112^{* * *}$ & 0.485 \\
Board independence & $-0.845^{* * *}$ & 0.004 \\
Family ownership & $-0.019 * *$ & 0.007 \\
Foreign institutional investors & $-0.004^{*}$ & 0.009 \\
Banks and FI & $0.034^{* * *}$ & 0.201 \\
BG Affiliation & $-0.38^{*}$ & 0.010 \\
Exports & $0.005^{* *}$ & 0.006 \\
R\&D Intensity & -0.681 & 0.074 \\
Firm size & $0.386^{* * *}$ & 0.006 \\
ROA & $-0.007^{* *}$ & 0.002 \\
DE & $0.006^{*}$ & 0.004 \\
Age & -0.0017 & \\
N & 6315 & $360.63 * * *$ \\
Wald Chi-Squared & & \\
\hline Heckman stage 2, DV: & \\
\hline
\end{tabular}

Heckman stage 2, DV: Internationalization, measured as ESTS

\begin{tabular}{lll}
\hline Explanatory variables & $\beta$-value & SD \\
\hline Lender proportion & $-0.080^{* *}$ & 0.208 \\
Board Size & -0.111 & 0.134 \\
Board independence & $-0.305^{* *}$ & 0.840 \\
Family ownership & $-0.160^{* * *}$ & 0.024 \\
Foreign institutional investors & $0.045^{*}$ & 0.042 \\
Banks and FI & $-0.320^{* *}$ & 0.084 \\
BG Affiliation & 0.068 & 0.779 \\
Firm size & $0.817 *$ & 0.359 \\
R\&D Intensity & -0.742 & 0.332 \\
ROA & $-0.058^{*}$ & 0.041 \\
DE & 0.002 & 0.025 \\
Age & $-0.048^{* *}$ & 0.018 \\
Interactions & & \\
Family* Lender & $0.795^{* *}$ & 0.33 \\
FII* Lender & $-0.777^{* *}$ & 0.555 \\
Bank-FI* Lender & $-0.814^{*}$ & 0.801 \\
Lambda & $1.477^{*}$ & 0.807 \\
N & 5513 & \\
Wald Chi-Squared & $137.79^{* * *}$ & 25.3 \\
R & & \\
\hline
\end{tabular}


Table 3 (continued)

All explanatory variables have been lagged by one year. Industry and year have been controlled for, but not reported

$* * * \mathrm{p}<0.001 * * \mathrm{p}<0.01 * \mathrm{p}<0.05$

strategic choices (Aguilera \& Jackson, 2003). We add to that literature by highlighting that lender representatives on board are a unique characteristic of debt financing economies, consequently affecting the strategic decision making amongst the different actors shaped by this institutional environment. This also leads us to conclude that lender representation on board can act as an institutional hazard (Nuruzamman et al., 2020) that can lower the chances of internationalization of firms.

In addition, we also find that the behaviour of lender representatives is modified by the presence of other major ownership groups in the firm. This shows that the extent to which lender representation on board is an institutional hazard can be modified by the presence of other actors in the firm. One of the surprising outcomes of our study is that while it is understood that foreign institutional investors affect internationalization choices positively (Bhaumik et al., 2010; Panicker et al., 2019), their presence negatively moderates the relation between lender representatives and internationalization. Despite the presence of foreign institutional investors who have the interest and capacity to undertake high risk, we find that foreign institutional investor shareholdings do not improve the risk-taking appetite of domestic lenders. We posit that this could be because of two reasons. First, their short-term preferences and wide-ranging portfolios (Douma et al., 2006) could result in frequent liquidation of shares and exit from the firm, which would not help build confidence in lender representatives. Second, the ability of foreign institutional investors to

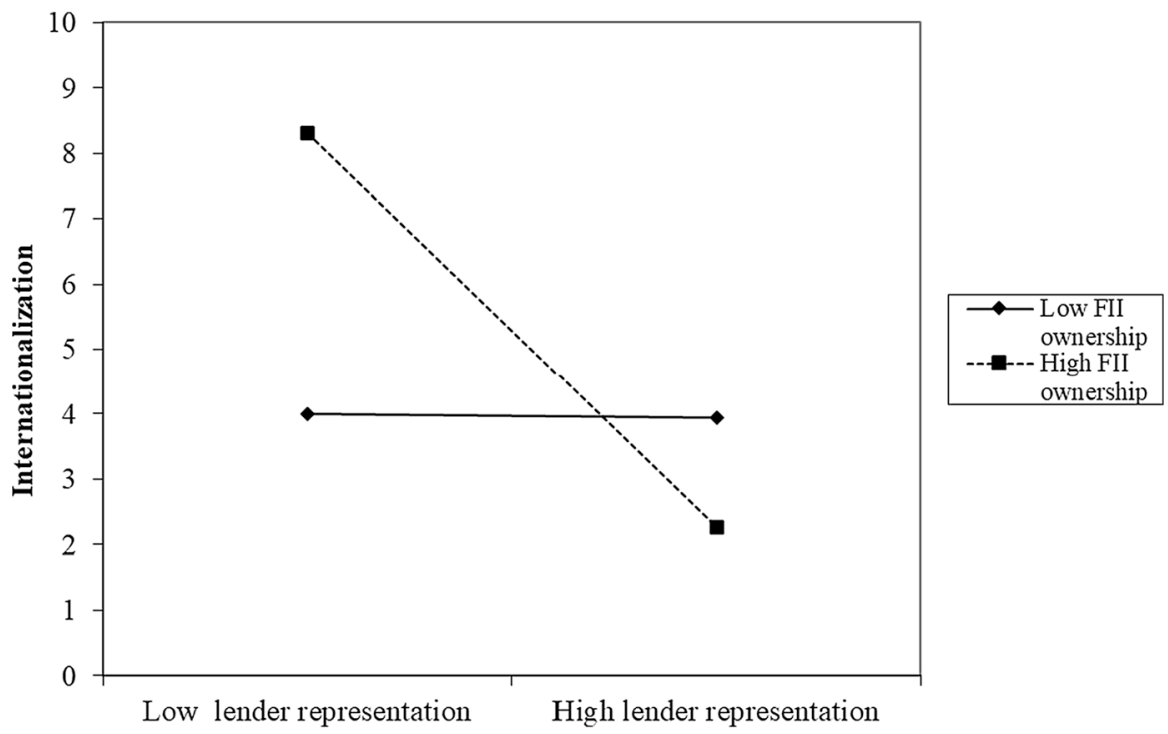

Fig. 1 Moderating effect of foreign institutional investor ownership on Lender representative-internationalization relation 
monitor internationalization may not be known or available to lender representative on the board. Consequently, the presence of foreign institutional investors who have high propensity for internationalization further urges the lending institutions to oppose such activities in firms, through their representatives on the board. The moderating effect of foreign institutional investor ownership on lender representativeinternationalization relation is demonstrated in Fig. 1.

However, we find that lender representatives support internationalization investments in firms with greater family ownership. Figure 2 demonstrates this moderating effect. While lender representatives have low risk-propensity and may not have the capacity to evaluate the internationalization investments, family ownership or controlling ownership ability to share information on internationalization would change their overall preference for internationalization. Family ownership can also result in overlapping, social ties with lenders and lower the overall risk perception of lender representatives towards internationalization. Therefore, improved information flow and lower information asymmetry due to their presence on the board of a family firm, induces greater confidence in lenders to support international activities of the firm. Alternately, their presence could also lower overall cost of capital for the firm.

Finally, we find that domestic institutional investors such as banks and other financial institutions also moderate the relationship between lending firms and internationalization. This result is interesting at many levels. First, in many firms, the same banks are present in a firm as both lender as well as investor. This duality creates conflict of interest within different section of a lending firm. However, we find that the preferences of the banks as a lender prevails over that as an investor. At the same time, we also find that since banks and financial institutions do not have the expertise or experience in specialized investment strategies such as

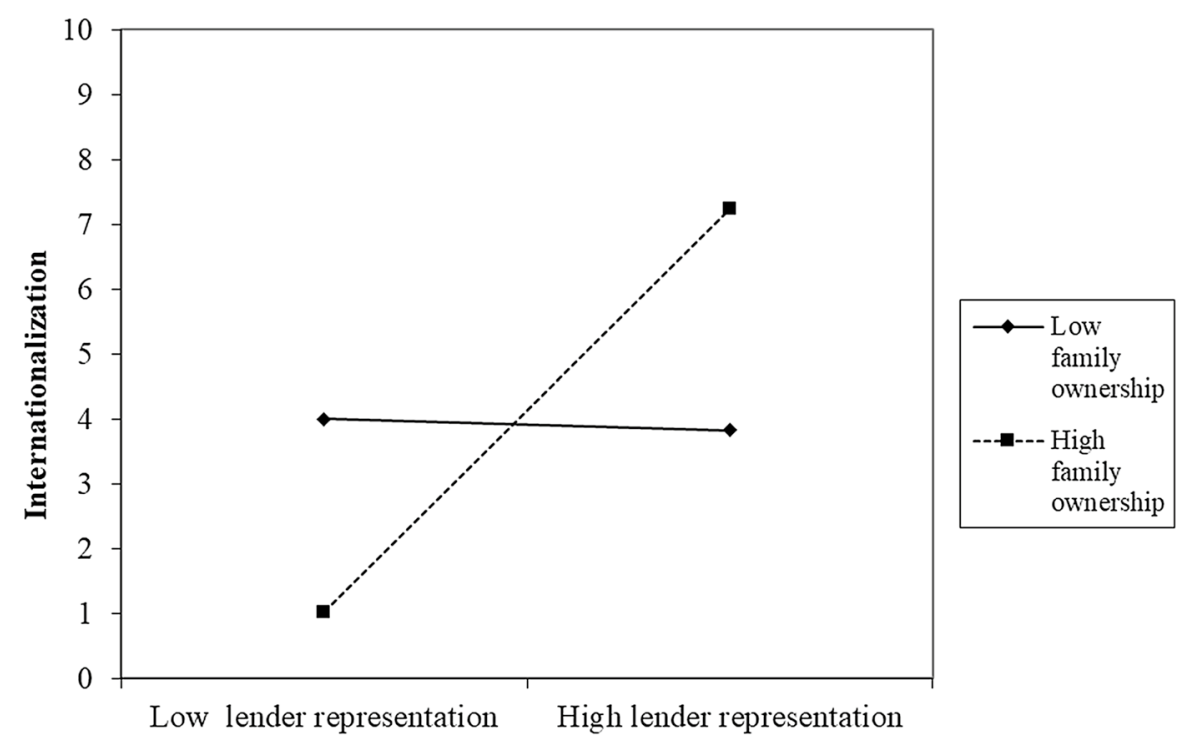

Fig. 2 Moderating effect of family ownership on Lender representative-internationalization relation 


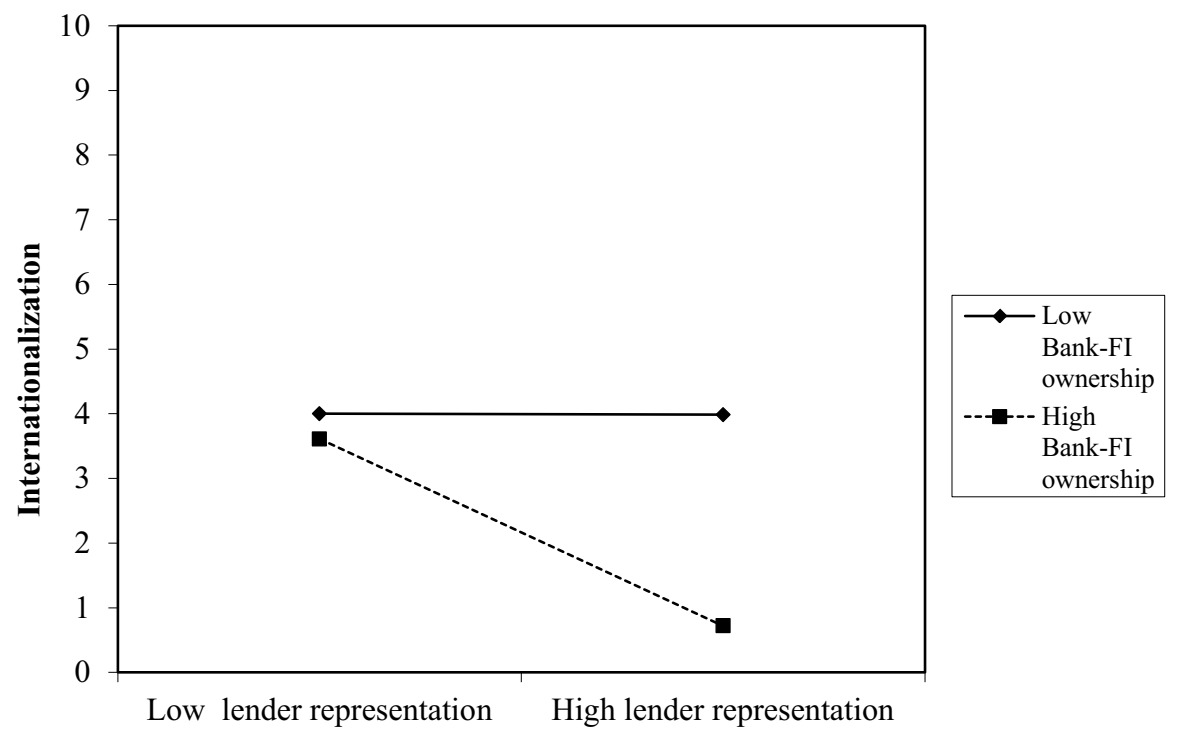

Fig. 3 Moderating effect of bank and financial institutional ownership on Lender representative-internationalization relation

internationalization, an increased shareholding by this category of owner does not provide confidence to lenders to support firm internationalization. This interaction is demonstrated in Fig. 3.

\subsection{Theoretical and managerial implications}

Our study contributes to extant literature in the following ways. First, we extend key insights into the governance of firms by various stakeholders (in the form of the directors on the board). In contexts where debt and equity financing co-exist, multiple stakeholders interact and can potentially participate in decision making process through their presence in board of directors. In the context of emerging economy firms in India, our study sheds light on the implication of such interactions for strategic internationalization decisions of the firms. By doing so, we argue that the attitude of different stakeholder representatives in the board of directors, towards strategic decisions of firms are shaped by the broader institutional configuration in which they operate as in case of India. By employing the Varieties of Institutional Systems framework (Fainshmidt et al., 2018) in our study, we have been able to identify the idiosyncratic characteristics within a selected institutional context (India in our case), and their impact on the corporate governance systems and firm level decisions. While our evidence demonstrates that instead of being an institutional support mechanism, lenders and their representatives by extension are institutional hazards that can potentially hamper internationalization of firms, their interaction with other institutional actors such as family owners can lower this effect. Finally, 
we also see that examining only specific characteristics of the board (such as board independence) without considering the specific institutional context within which a firm is situated will paint an incomplete picture in terms of board contributions. For instance, we find that unlike the independent directors' resource provisioning role, the lender representatives' priority of recovering debt extended to firms, compels them to dissuade internationalization of such firms. This could be because while independent directors often could provide resources, the lender representatives play a key monitoring role of protecting their own debt. Since the board behaviour is shaped by their roles arising broadly out of the context of the institutional underpinning in which they are embedded, it is imperative to have a deeper interpretation of institutional agency theory for firms situated in non-Anglo-Saxon economies.

One of the key managerial implication of our study is that foreign institutional investors need to be aware of strategic decision outcome of such high debt firms having lender representative on the board of directors. Family ownership can get the buy-in of lender representatives by sharing appropriate and requisite information on internationalization with them. Hence enhancing family ownership could serve as a signal for lenders to support internationalization. In addition, regulators should try and enhance the capacities of both the financial institutions as well as their representatives. This would consequently enhance their ability to evaluate the internationalization opportunities of firm in a better manner.

We also identify certain limitations of our study. First, we acknowledge that there are differences among different countries that follow a bank-centred model of corporate governance. The national level institutions are instrumental in determining the effectiveness of different corporate governance systems, and hence further studies need to be undertaken in different contexts to confirm if our findings are generalizable across different national contexts. Second, in this study, we have calculated the shareholding by banks and financial institutions combined. It is possible that a bank behaves differently from a developmental financial institution. However, we could not test this due to the unavailability of data. Third, the preference of lending institutions for internationalization investments will also depend on the kind of FDI (market-seeking versus strategic asset-seeking), however, due to the limited availability of data, this difference could also not be verified in our study.

Open Access This article is licensed under a Creative Commons Attribution 4.0 International License, which permits use, sharing, adaptation, distribution and reproduction in any medium or format, as long as you give appropriate credit to the original author(s) and the source, provide a link to the Creative Commons licence, and indicate if changes were made. The images or other third party material in this article are included in the article's Creative Commons licence, unless indicated otherwise in a credit line to the material. If material is not included in the article's Creative Commons licence and your intended use is not permitted by statutory regulation or exceeds the permitted use, you will need to obtain permission directly from the copyright holder. To view a copy of this licence, visit http://creativecommons.org/licen ses/by/4.0/. 


\section{References}

Abraham, S., Marston, C., \& Jones, E. (2015). Disclosure by Indian companies following corporate governance reform. Journal of Applied Accounting Research, 16(1), 114-137.

Aguilera, R. V., \& Grøgaard, B. (2019). The dubious role of institutions in international business: A road forward. Journal of International Business Studies, 50(1), 20-35.

Aguilera, R. V., \& Jackson, G. (2003). The cross-national diversity of corporate governance: Dimensions and determinants. Academy of Management Review, 28(3), 447-465.

Aguilera, R. V., \& Yip, G. S. (2004). Corporate governance and globalization: Toward an actor-centred institutional analysis. In A. Ariño (Ed.), Creating value through international strategy (pp. 55-67). Palgrave Macmillan.

Arregle, J. L., Hitt, M. A., Sirmon, D. G., \& Very, P. (2007). The development of organizational social capital: Attributes of family firms. Journal of Management Studies, 44(1), 73-95.

Ashwin, A. S., Krishnan, R. T., \& George, R. (2015). Family firms in India: Family involvement, innovation and agency and stewardship behaviors. Asia Pacific Journal of Management, 32(4), 869-900.

Balasubramanian, B. N., \& Anand, R. (2013). Ownership trends in corporate India 2001-2011: Evidence and implications. IIM Bangalore Research Paper, p. 419.

Band, D. (1992). Corporate governance: Why agency theory is not enough. European Management Journal, 10(4), 453-459.

Bao, S. R., \& Lewellyn, K. B. (2017). Ownership structure and earnings management in emerging markets: An institutionalized agency perspective. International Business Review, 26(5), 828-838.

Baysinger, B. D., \& Butler, H. N. (1985). Corporate governance and the board of directors: Performance effects of changes in board composition. Journal of Law, Economics, \& Organization, 1(1), 101-124.

Baysinger, B., \& Hoskisson, R. E. (1990). The composition of boards of directors and strategic control: Effects on corporate strategy. Academy of Management Review, 15(1), 72-87.

Becker, B., \& Strömberg, P. (2012). Fiduciary duties and equity-debtholder conflicts. The Review of Financial Studies, 25(6), 1931-1969.

Bhaumik, S. K., Driffield, N., \& Pal, S. (2010). Does ownership structure of emerging-market firms affect their outward FDI? The case of the Indian automotive and pharmaceutical sectors. Journal of International Business Studies, 41(3), 437-450.

Black, B. S. (1992). Agents watching agents: The promise of financial intermediary voice. UCLA Law Review, 39(4), 811-893.

Bodnaruk, A., Massa, M., \& Zeume, S. (2012). Country governance and foreign investment in business groups. Available at SSRN 2021049.

Boubaker, S., Derouiche, I., \& Nguyen, D. K. (2015). Does the board of directors affect cash holdings? A study of French listed firms. Journal of Management \& Governance, 19(2), 341-370.

Boyd, B. K. (1994). Board control and CEO compensation. Strategic Management Journal, 15(5), 335-344.

Byrd, D. T., \& Mizruchi, M. S. (2005). Bankers on the board and the debt ratio of firms. Journal of Corporate Finance, 11(1-2), 129-173.

Chang, S. J., \& Choi, U. (1988). Strategy, structure and performance of Korean business groups: A transactions cost approach. The Journal of Industrial Economics, 37, 141-158.

Chirinko, R. S., \& Elston, J. A. (2006). Finance, control and profitability: The influence of German banks. Journal of Economic Behavior \& Organization, 59(1), 69-88.

Clarke, J. E., \& Liesch, P. W. (2017). Wait-and-see strategy: Risk management in the internationalization process model. Journal of International Business Studies, 48(8), 923-940.

Dalton, D. R., Daily, C. M., Ellstrand, A. E., \& Johnson, J. L. (1998). Meta-analytic reviews of board composition, leadership structure, and financial performance. Strategic Management Journal, 19(3), 269-290.

Dalton, D. R., Hitt, M. A., Certo, S. T., \& Dalton, C. M. (2007). 1 the fundamental agency problem and its mitigation: Independence, equity, and the market for corporate control. The Academy of Management Annals, 1(1), 1-64.

Dewatripont, M., \& Tirole, J. (1994). A theory of debt and equity: Diversity of securities and managershareholder congruence. The Quarterly Journal of Economics, 109(4), 1027-1054.

Dharwadkar, B., George, G., \& Brandes, P. (2000). Privatization in emerging economies: An agency theory perspective. Academy of Management Review, 25(3), 650-669. 
Dittmann, I., Maug, E., \& Schneider, C. (2009). Bankers on the boards of German firms: What they do, what they are worth, and why they are (still) there. Review of Finance, 14(1), 35-71.

Djelic, M. L. (2001). Exporting the American model: The post-war transformation of European business. Oxford University Press.

Douma, S., George, R., \& Kabir, R. (2006). Foreign and domestic ownership, business groups, and firm performance: Evidence from a large emerging market. Strategic Management Journal, 27(7), 637-657.

Drori, G. S., Meyer, J. W., Ramirez, F. O., \& Schofer, E. (2003). Introduction: Science as a world institution. Science in the modern world polity: Institutionalization and globalization, pp. 1-22.

Dvořák, T. (2005). Do domestic investors have an information advantage? Evidence from Indonesia. The Journal of Finance, 60(2), 817-839.

Dwivedi, N., \& Jain, A. K. (2005). Corporate governance and performance of Indian firms: The effect of board size and ownership. Employee Responsibilities and Rights Journal, 17(3), 161-172.

Fainshmidt, S., Judge, W. Q., Aguilera, R. V., \& Smith, A. (2018). Varieties of institutional systems: A contextual taxonomy of understudied countries. Journal of World Business, 53(3), 307-322.

Fama, E. F. (1985). What's different about banks? Journal of Monetary Economics, 15(1), 29-39.

Fernández, Z., \& Nieto, M. J. (2005). Internationalization strategy of small and medium-sized family businesses: Some influential factors. Family Business Review, 18(1), 77-89.

Fiss, P. C., \& Zajac, E. J. (2004). The diffusion of ideas over contested terrain: The (non) adoption of a shareholder value orientation among German firms. Administrative Science Quarterly, 49(4), 501-534.

Freeman, E., \& Liedtka, J. (1997). Stakeholder capitalism and the value chain. European Management Journal, 15(3), 286-296.

Freeman, R. E., Martin, K., \& Parmar, B. (2007). Stakeholder capitalism. Journal of Business Ethics, 74(4), 303-314.

Fuad, M., \& Gaur, A. S. (2019). Merger waves, entry-timing, and cross-border acquisition completion: A frictional lens perspective. Journal of World Business, 54(2), 107-118.

Gaur, A. S., \& Kumar, V. (2009). International diversification, business group affiliation and firm performance: Empirical evidence from India. British Journal of Management, 20(2), 172-186.

George, G., Wiklund, J., \& Zahra, S. A. (2005). Ownership and the internationalization of small firms. Journal of Management, 31(2), 210-233.

Gerlach, J. D., Williams, L. K., \& Forcina, C. E. (2013). Data selection for making biodiversity management decisions: Best available science and institutionalized agency norms. Administration \& Society, 45(2), 213-241.

Ghosh, S. (2016). Banker on board and innovative activity. Journal of Business Research, 69(10), 4205-4214.

Giannetti, M., \& Ongena, S. (2005). Financial integration and entrepreneurial activity: Evidence from foreign bank entry in emerging markets. Working paper, Center for Economic Policy and Research.

Gillan, S., \& Starks, L. T. (2003). Corporate governance, corporate ownership, and the role of institutional investors: A global perspective. Journal of Applied Finance, 13(2), 4-22.

Goldberg, L., Dages, B. G., \& Kinney, D. (2000). Foreign and domestic bank participation in emerging markets: Lessons from Mexico and Argentina (No. w7714). National Bureau of Economic Research.

Gómez-Mejía, L. R., Haynes, K. T., Núñez-Nickel, M., Jacobson, K. J., \& Moyano-Fuentes, J. (2007). Socioemotional wealth and business risks in family-controlled firms: Evidence from Spanish olive oil mills. Administrative Science Quarterly, 52(1), 106-137.

Goodstein, J., Gautam, K., \& Boeker, W. (1994). The effects of board size and diversity on strategic change. Strategic Management Journal, 15(3), 241-250.

Greenwood, R., Hinings, C. R., \& Whetten, D. (2014). Rethinking institutions and organizations. Journal of Management Studies, 51(7), 1206-1220.

Hall, P. A., \& Soskice, D. (2001). An introduction to varieties of capitalism. In P. A. Hall \& D. Soskice (Eds.), Varieties of capitalism: The institutional foundations of comparative advantage (pp. 1-70). Oxford University Press.

Heckman, J. J. (1976). The common structure of statistical models of truncation, sample selection and limited dependent variables and a simple estimator for such models. Annals of Economic and Social Measurement, 5(4), 475-492.

Hilscher, J., \& Şişli-Ciamarra, E. (2013). Conflicts of interest on corporate boards: The effect of creditordirectors on acquisitions. Journal of Corporate Finance, 19, 140-158. 
Hopt, K. J., \& Leyens, P. C. (2004). Board models in Europe-recent developments of internal corporate governance structures in Germany, the United Kingdom, France, and Italy. European Company and Financial Law Review, 1(2), 135-168.

Huang, W., \& Zhu, T. (2015). Foreign institutional investors and corporate governance in emerging markets: Evidence of a split-share structure reform in China. Journal of Corporate Finance, 32, 312-326.

Immergut, E. M. (1998). The theoretical core of the new institutionalism. Politics \& Society, 26(1), 5-34.

Jackson, G., \& Deeg, R. (2008). Comparing capitalisms: Understanding institutional diversity and its implications for international business. Journal of International Business Studies, 39(4), 540-561.

Jaiswall, M., \& Banerjee, A. (2012). Exploring the relationship between Earnings Management and Corporate Governance characteristics in the Indian context. IIM Calcutta WPS No, p. 704.

James, C. (1987). Some evidence on the uniqueness of bank loans. Journal of Financial Economics, 19(2), 217-235.

Jensen, M. C. (1986). Agency costs of free cash flow, corporate finance, and takeovers. The American Economic Review, 76(2), 323-329.

Jensen, M. C., \& Meckling, W. H. (1976). Theory of the firm: Managerial behavior, agency costs and ownership structure. Journal of Financial Economics, 3(4), 305-360.

Johanson, J., \& Vahlne, J. E. (2009). The Uppsala internationalization process model revisited: From liability of foreignness to liability of outsidership. Journal of International Business Studies, 40(9), 1411-1431.

Kang, M. J., \& Kim, A. (2017). Bankers on the board and CEO incentives. European Financial Management, 23(2), 292-324.

Khanna, T., \& Palepu, K. (1997). Why focused strategies may be wrong for emerging markets. Harvard Business Review, 75, 41-54.

Khanna, T., \& Palepu, K. (2000). Emerging market business groups, foreign intermediaries, and corporate governance. Concentrated corporate ownership (pp. 265-294). University of Chicago Press.

Khanna, T., \& Rivkin, J. W. (2001). Estimating the performance effects of business groups in emerging markets. Strategic Management Journal, 22(1), 45-74.

Kracaw, W. A., \& Zenner, M. (1998). Bankers in the boardroom: Good news or bad news. Unpublished working paper. Pennsylvania: Pennsylvania State University.

Kroszner, R. S., \& Strahan, P. E. (2001). Bankers on boards: Monitoring, conflicts of interest, and lender liability. Journal of Financial Economics, 62(3), 415-452.

Lien, Y. C., Piesse, J., Strange, R., \& Filatotchev, I. (2005). The role of corporate governance in FDI decisions: Evidence from Taiwan. International Business Review, 14(6), 739-763.

Lin, W. T. (2012). Family ownership and internationalization processes: Internationalization pace, internationalization scope, and internationalization rhythm. European Management Journal, 30(1), 47-56.

Lu, J., Liu, X., Wright, M., \& Filatotchev, I. (2014). International experience and FDI location choices of Chinese firms: The moderating effects of home country government support and host country institutions. Journal of International Business Studies, 45(4), 428-449.

Luo, Y., \& Rui, H. (2009). An ambidexterity perspective toward multinational enterprises from emerging economies. Academy of Management Perspectives, 23(4), 49-70.

Maher, M., \& Andersson, T. (2002). Corporate governance: Effects on firm performance and economic growth. Convergence and diversity in corporate governance regimes and capital markets (pp. 386420). Oxford University Press.

Melis, A., Carta, S., \& Gaia, S. (2012). Executive remuneration in blockholder-dominated firms. How do Italian firms use stock options? Journal of Management \& Governance, 16(3), 511-541.

Miller, K. D. (1992). A framework for integrated risk management in international business. Journal of International Business Studies, 23(2), 311-331.

Molly, V., Laveren, E., \& Deloof, M. (2010). Family business succession and its impact on financial structure and performance. Family Business Review, 23(2), 131-147.

Morck, R., Wolfenzon, D., \& Yeung, B. (2005). Corporate governance, economic entrenchment, and growth. Journal of Economic Literature, 43(3), 655-720.

Musacchio, A., Lazzarini, S. G., \& Aguilera, R. V. (2015). New varieties of state capitalism: Strategic and governance implications. Academy of Management Perspectives, 29(1), 115-131.

Nachane, D. M., Ghosh, S., \& Ray, P. (2005). Bank nominee directors and corporate performance: Microevidence for India. Economic and Political Weekly, 40, 1216-1223. 
Nuruzzaman, N., Singh, D., \& Gaur, A. S. (2020). Institutional support, hazards, and internationalization of emerging market firms. Global Strategy Journal, 10(2), 361-385.

Pajunen, K. (2008). Institutions and inflows of foreign direct investment: A fuzzy-set analysis. Journal of International Business Studies, 39(4), 652-669.

Pan, X., \& Tian, G. G. (2015). Does banks' dual holding affect bank lending and firms' investment decisions? Evidence from China. Journal of Banking \& Finance, 55, 406-424.

Panicker, V. S., \& Upadhyayula, R. S. (2020). Limiting role of resource dependence: An examination of director interlocks, board meetings and family ownership. Cross Cultural \& Strategic Management.

Panicker, V. S., Mitra, S., \& Upadhyayula, R. S. (2019). Institutional investors and international investments in emerging economy firms: A behavioral risk perspective. Journal of World Business, 54(4), 322-334.

Pucheta-Martínez, M. C., \& García-Meca, E. (2014). Institutional investors on boards and audit committees and their effects on financial reporting quality. Corporate Governance: An International Review, 22(4), 347-363.

Purkayastha, S., Manolova, T. S., \& Edelman, L. F. (2018). Business group effects on the R\&D intensity-internationalization relationship: Empirical evidence from India. Journal of World Business, 53(2), 104-117.

Ramamurti, R., \& Singh, J. V. (Eds.). (2009). Emerging multinationals in emerging markets. Cambridge University Press.

Ray, S., Mondal, A., \& Ramachandran, K. (2018). How does family involvement affect a firm's internationalization? An investigation of Indian family firms. Global Strategy Journal, 8(1), 73-105.

Ruzzier, M., \& Antoncic, B. (2007). Social capital and SME internationalization: An empirical examination. Transformations in Business \& Economics, 6(1), 20.

Sánchez-Bueno, M. J., \& Usero, B. (2014). How may the nature of family firms explain the decisions concerning international diversification? Journal of Business Research, 67(7), 1311-1320.

Sarkar, J. (2010). Ownership and corporate governance in Indian firms. Corporate governance: An emerging scenario. National Stock Exchange of India Ltd, pp. 217-267.

Sarkar, J., \& Sarkar, S. (2000). Large shareholder activism in corporate governance in developing countries: Evidence from India. International Review of Finance, 1(3), 161-194.

Sartori, A. E. (2003). An estimator for some binary-outcome selection models without exclusion restrictions. Political Analysis, 11(2), 111-138.

Scharpf, F. W. (2018). Games real actors play: Actor-centered institutionalism in policy research. Routledge.

Seal, W. (2006). Management accounting and corporate governance: An institutional interpretation of the agency problem. Management Accounting Research, 17(4), 389-408.

Shleifer, A., \& Vishny, R. W. (1997). A survey of corporate governance. The Journal of Finance, 52(2), 737-783.

Singh, C. (1999). Domestic debt and economic growth in India. Economic and Political Weekly, 34, 1445-1453.

Singh, D., \& Delios, A. (2017). Corporate governance, board networks and growth in domestic and international markets: Evidence from India. Journal of World Business, 52(5), 615-627.

Singh, D. A., \& Gaur, A. S. (2013). Governance structure, innovation and internationalization: Evidence from India. Journal of International Management, 19(3), 300-309.

Singla, C., Veliyath, R., \& George, R. (2014). Family firms and internationalization-governance relationships: Evidence of secondary agency issues. Strategic Management Journal, 35(4), 606-616.

Suddaby, R., Seidl, D., \& Le, J. (2013). Strategy-as-practice meets neoinstitutional theory. Strategic Organization, 11(3), 329-344.

Tee, C. M. (2018). Political connections, institutional monitoring and the cost of debt: Evidence from Malaysian firms. International Journal of Managerial Finance, 14(2), 210-229.

Tsui-Auch, L. S., \& Lee, Y. J. (2003). The state matters: Management models of Singaporean Chinese and Korean business groups. Organization Studies, 24(4), 507-534.

Tuschke, A., \& Gerard Sanders, W. (2003). Antecedents and consequences of corporate governance reform: The case of Germany. Strategic Management Journal, 24(7), 631-649.

Vahlne, J. E., \& Johanson, J. (2013). The Uppsala model on evolution of the multinational business enterprise-from internalization to coordination of networks. International Marketing Review., 30(3), 189-210. 
Van den Berghe, L. A., \& Levrau, A. (2004). Evaluating boards of directors: What constitutes a good corporate board? Corporate Governance: An International Review, 12(4), 461-478.

Welch, I. (1997). Why is bank debt senior? A theory of asymmetry and claim priority based on influence costs. The Review of Financial Studies, 10(4), 1203-1236.

Wernerfelt, B., \& Karnani, A. (1987). Competitive strategy under uncertainty. Strategic Management Journal, 8(2), 187-194.

Whitley, R. (1999). Divergent capitalisms: The social structuring and change of business systems. Oxford University Press.

Witt, M. A., \& Lewin, A. Y. (2007). Outward foreign direct investment as escape response to home country institutional constraints. Journal of International Business Studies, 38(4), 579-594.

Wooldridge, J. (2002). Econometric analysis of cross section and panel data. MIT Press.

World Bank. 2005. India: Role of institutional investors in the corporate governance of their portfolio companies, World Bank Publication. Retrieved from http://www.nfcgindia.org/final_indiajune29.pdf

Yoshikawa, T., \& Phan, P. H. (2005). The effects of ownership and capital structure on board composition and strategic diversification in Japanese corporations. Corporate Governance: An International Review, 13(2), 303-312.

Young, M. N., Peng, M. W., Ahlstrom, D., Bruton, G. D., \& Jiang, Y. (2008). Corporate governance in emerging economies: A review of the principal-principal perspective. Journal of Management Studies, 45(1), 196-220.

Publisher's Note Springer Nature remains neutral with regard to jurisdictional claims in published maps and institutional affiliations.

Vidya Sukumara Panicker is a Lecturer in International Business in the School of Business and Economics, Loughborough University, United Kingdom. Her core research areas include emerging markets, corporate governance, and international business. Her research has been published in journals including Journal of World Business, Cross Cultural and Strategic Management and Social Responsibility Journal.

Rajesh Srinivas Upadhyayula is a Professor of Strategic Management at Indian Institute of Management Kozhikode, Kerala. His current research interests are in the areas of speed, governance issues, location or clustering, institutional distance of emerging market multinationals and international new ventures and born globals. He has in research published in journals such as Journal of World Business, Journal of International Management and Journal of Business Research, among others.

Sumit Mitra is Professor of Strategic Management at Indian Institute of Management Kozhikode, Kerala. His current research interests include Social Entrepreneurship, Corporate Governance and Higher Education. His work has previously been published in journals such as Journal of World Business, Management and Organization Review and Benchmarking: An International Journal, among others. 